\title{
Interpreting 'Torah' in Psalm 1 in the light of Psalm 119
}

\begin{abstract}
Author:
Philippus J. Botha ${ }^{1}$

Affiliation:

${ }^{1}$ Department of Ancient

Languages, University of

Pretoria, South Africa

Correspondence to:

Phil Botha

Email:

phil.botha@up.ac.za

\section{Postal address:}

Department of Ancient

Languages, University of

Pretoria, Hatfield Campus,

Pretoria 0001, South Africa

\section{Dates:}

Received: 02 June 2012

Accepted: 07 Sept. 2012

Published: 08 Nov. 2012

How to cite this article: Botha, P.J., 2012,

'Interpreting "Torah" in Psalm 1 in the light of Psalm 119', HTS Teologiese Studies/ Theological Studies 68(1), Art. \#1274, 7 pages. http:// dx.doi.org/10.4102/hts. v68i1.1274
\end{abstract}

(C) 2012. The Authors. Licensee: AOSIS OpenJournals. This work is licensed under the Creative Commons Attribution License.
This article argued that Psalm 37 and Proverbs 1-4 served as sources for the composition of Psalm 1. The emphasis in both donor texts on the righteous people's inheriting the Promised Land seems to have imprinted also on Psalm 1, a factor that could change our understanding of it. All three contexts in turn played a role in the composition of Psalm 119, but whilst the author of this long psalm also understood the 'Torah' of Yahweh as the incarnation of true wisdom, it seems that 'Torah' also subsumed the Promised Land for him. The investigation showed that 'Torah' in Psalm 1 should be understood as an arch-lexeme for all the religious texts its author used to compose, similar to what was the understanding of the author of Psalm 119 a little later.

\section{Introduction}

It stands to the credit of Alfons Deißler to have shown convincingly that Psalm 119 was composed in what he called the 'anthological style Gattung' (anthologische Stilgattung) - a way of creating Scripture through the creative use of Scripture. ${ }^{1}$ By alluding to, borrowing from, rephrasing, and reinterpreting segments of the Torah, Prophets, wisdom literature, and Psalms, the author of Psalm 119 created a new authoritative text by replicating and re-contextualising what must have been considered to be authoritative texts in his day. ${ }^{2}$ By doing so, he gave a clear indication of what he considered to be included under 'Torah' in its general sense. ${ }^{3}$ His use of the eight 'synonyms' for 'Torah' suggests that it concerns the regulation of human action as much as it does the descriptions of acts of salvation by Yahweh in the past and the promises about his future intervention in the life of the faithful. ${ }^{4}$

What is coming more and more to light in recent research is that Psalm 119 was not the first psalm to be created on this basis. It seems that the author had examples to follow: many of the psalms that played an important role in the composition of Psalm 119 already - but to a lesser extent made use of this mode of composition. In this regard I refer especially to Psalms 19 and 37 which will be touched upon in this article. ${ }^{5}$ But his primary example of this post-exilic style of creating religious texts must have been Psalm $1 .^{6}$ The author of Psalm 1, it seems, made use of phrases and images from Deuteronomy, ${ }^{7}$ Joshua, Jeremiah, Ezekiel, and Psalms. ${ }^{8}$ To these well-known sources for the composition of Psalm 1, I would like to add the first chapters of Proverbs and from among the Psalms, Psalm 37 in particular. The connection between Psalm 37 and Proverbs surely played a role in establishing (indirect) connecting lines between Psalm 1 and Proverbs, but I believe Proverbs itself also made a direct impact on Psalm 1. Finally, I would also like

1.'Für seinen Psalm vom Worte Jahwes wollte der Autor das ihm vorliegende schriftliche Wort Gottes möglichst selbst zur Sprache kommen lassen bzw. in seinem Sprechen aus der Schilderung seiner Meditation und Erfahrung heraus an ihm anknüpfen' (Deißler 1955:268, cf. also 277).

2.Deißler speaks of 'der überkommenen heiligen Texte' (1955:277).

3.The word תורה functions as the arch-lexeme of Torah-words in Psalm 119, although the term דבר of is used in very much the same way and thus is a close contender for the position. Cf. Botha (1989-20-21). This serves as proof that much more than 'Mosaic' material was intended. Weber (2006:88-89) infers the same to be true of the use of תin in Psalm 1.

4.Cf. my thesis, Botha (1986), and the article on the role of each term in the semantic field, Botha (1989:3-22).

5.Other psalms which were composed or edited by exponents of wisdom are too many to be listed here. Reference can be made to the important contribution of Bernard Gosse (2008:51-210) and my own more modest investigations into Psalm 12 (Botha 2012b:260276), Psalm 24 (Botha 2010:43-58), Psalm 26 (Botha 2011a:30-48), Psalm 31 (Botha 2011b:424-442), Psalm 33 (Botha \& Potgieter 2010:1-8), Psalm 34 (Botha 2008:18-37), and Psalm 91 (Botha 2012b:260-276).

6.Creach $(1999: 36$, n. 6) speaks of the author of the psalm altering and transcending "his "sources" in such an orderly fashion that the psalm may be said to contain a kind of "exegesis".

7.In this regard, the most comprehensive investigation probably is the study of Weber (2007:179-200). He focuses on the influence of Deuteronomy 6:4-9 as key context, recognisable through the use of certain terms and the theme of memorising the Torah. Cf. also Weber (2006:89-92). The influence of other biblical contexts has (inter alia) been investigated in the studies of Creach (1999), Botha (2005), Weber (2006) and Weber (2010).

8.Christoph Levin has pointed out many contacts with other psalms, amongst which the significant similarity between Psalm 1:6 and Psalm 146:8b and 9b. Cf. Levin (1993:362). A number of exegetes also find interplay with Malachi 3, for exampe Hossfeld and Zenger (1993:45) and Reinhard Kratz (1996:7). Malachi 3:19 (MT) does mention the wicked as 'stubble' (שק instead of מ מ ) and 3:22 does mention the 'Torah of Moses,' whilst the wicked and the righteous are also contrasted. 
TABLE 1: The influence of Proverbs on Psalms 19, 1 and 119.

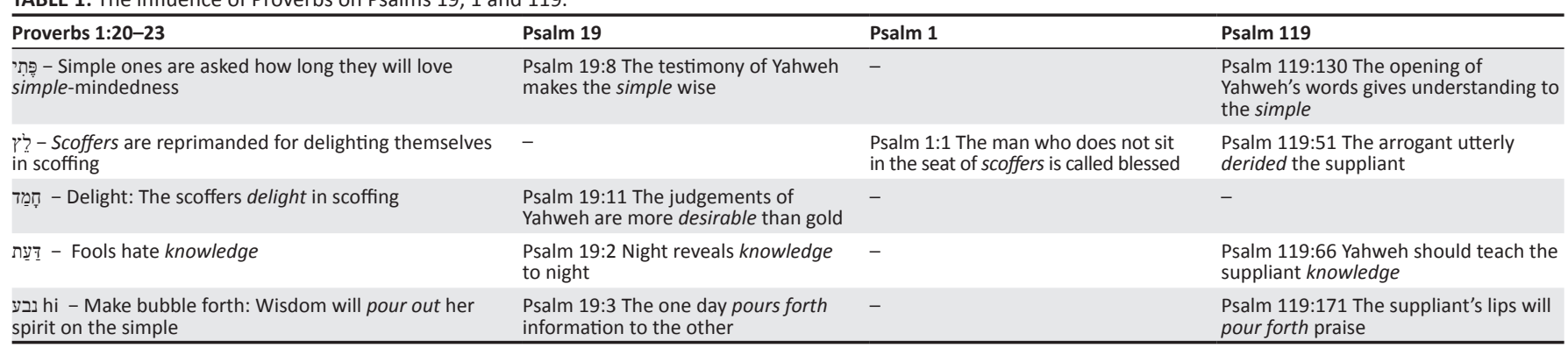

to point out that the author of Palm 119 considered Psalm 1 itself as an authoritative text, but did not hesitate to adapt and reinterpret it for his own circumstances. ${ }^{9}$

This article proposes to table arguments that will show how the authors of Psalms 1, 19, and 37 reinterpreted Proverbs 1-4 to define 'Torah' - which included wisdom teaching - as true wisdom. ${ }^{10}$ The author of Psalm 37 was particularly concerned with arguing that those who have the Torah of Yahweh in their heart (rather than wisdom as the psalm's 'base text,' $\operatorname{Pr} 2$, suggests) will 'inherit the land'. The connection between Psalm 1 and Psalm 37, I would further like to argue, implies that the author of Psalm 1 understood 'success' also as eventual inheritance of the Promised Land, and attachment to the Torah - as the complete revealed will of God (inclusive of wisdom texts) - as the way to achieve this. Finally, I would like to argue that the author of Psalm 119 understood 'Torah' in a similar way as the author of Psalm 37 and Psalm 1, but made a further adaptation to these wisdom psalms. Where Psalm 1 still implies (like Ps 37) that the way to success and blessedness is to walk in the Torah as true wisdom, the author of Psalm 119 argues that success and blessedness is to be able to walk in the Torah of Yahweh.

\section{Torah is true wisdom according to Psalms 19 and 37}

Bernard Gosse published a fine short article (Gosse 2006) in which he shows how Proverbs, especially Proverbs 1:20-23, served as inspiration for Psalms 1, 19 and 119. He focuses on the call of personified wisdom to the 'simple ones' and its reinterpretation in Psalms 19 and 119 to indicate that it is the Torah - in the form of the 'witness' of Yahweh (עָרוּת, Ps 19:8) and the 'words' of Yahweh (?ָּרָּרים, Ps 119:130) respectively - that gives wisdom and understanding to the simple ones. He also notes how the warning against 'scoffing' (in Pr 1:22) finds an echo in Psalms 1:1 and 119:51. His insight into the process of how Proverbs inspired or influenced these three wisdom psalms may be summarised as seen in Table 1 .

He also points out many other connections between Psalm 19 and Proverbs (such as the dependence of Ps 19:11 on

9.The question of which psalm preceded which will be touched upon a little later Cf. the valuable discussion on the dating of Psalm 1 in Weber (2006:95-97). One should acknowledge, however, that the date of writing is not necessarily relevant for determining the time when or place where a psalm was inserted into the Psalter.

10.These psalms are not the only ones with wisdom connections in Book I of the Psalter, but Psalm 19 is seen as the form-historical centre of the first book (Millard 1994:140) with connections to Psalm 1 in terms of Torah-piety and simila connections to the composition of Psalms 32-41 in terms of wisdom.
$\operatorname{Pr}$ 16:24 and 24:13). He shows convincingly how the language associated with the 'Torah' in Psalms 1, 19 and 119 uses the terminology associated with wisdom in the book of Proverbs.

There can be little doubt that the author of Psalm 19 drew inspiration from the book of Proverbs and that 'Torah,'

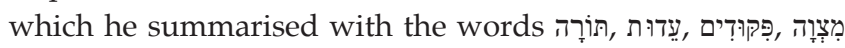
and in the book of Proverbs.

It seems to me that Psalm 37 has a similar connection with Proverbs. Zenger has pointed out the conspicuous similarities between Psalm 37:1 and Proverbs 24:1 and 19, as well as the similarity of Psalm 37:37-38 with Proverbs 24:20 (Hossfeld \& Zenger 1993:230). Wilson (2002:602) pointed out the similarity between Palms 37:16-17 and Proverbs 15:16. ${ }^{11}$ But it seems that Proverbs 2:20-22 ${ }^{12}$ was also considered particularly important by the author of Psalm 37. These verses read as follows:

20. So that you can walk in the way of good (men), and keep the paths of the righteous. 21. For the upright will live (שכן) in the land (ארץי), and the blameless will remain in it. 22. But the

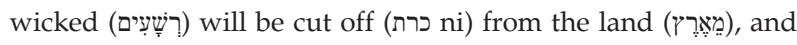
the faithless ones will be torn out from it.

This has a parallel in Psalm 37:5 and 9:

Commit your way to Yahweh, trust also in him, and he will do it ...

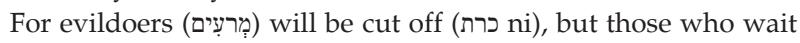
for Yahweh will inherit (ירשי) the land (ארץץ).

The idea of inheritance of the land is stressed through repetition in the rest of Psalm 37. It seems as if the whole Psalm actually comments on the text in Proverbs 2:

But the humble will inherit (ירש) the land, and will delight themselves in abundant prosperity (שלום רב) (Ps 37:11).

Yahweh knows the days of the blameless; and their inheritance (ניָדָלה Will be forever (Ps 37:18).

For those blessed by him will inherit (ירש) the land; but those cursed by him will be cut off (כרת ni) (Ps 37:22).

Depart from evil, and do good, so you will stay (שכן) forever. For Yahweh loves justice, and does not forsake his godly ones; they are preserved forever; but the descendants of the wicked will be cut off (כרת ni). The righteous will inherit (ירשן) the land, and dwell (שכן) in it forever (Ps 37:27-29).

11. He refers to Proverbs $16: 8$ and $28: 6$ as well.

12. Hossfeld and Zenger (1993:232) also refer to Proverbs 2:21-22. The same thought is also expressed in other words in Proverbs 10:30. 
TABLE 2: Similarities between Psalm 37:5-6 and Proverbs 4:18.

\begin{tabular}{|c|c|}
\hline Psalm 37:5-6 & Proverbs 4:18 \\
\hline $\begin{array}{l}\text { Commit your way (דרכך) to Yahweh, } \\
\text { trust also in him, and he will do it. And } \\
\text { he will bring forth your righteousness } \\
\text { as the light (כאור צדקר), and your } \\
\text { judgement as the midday (כצרים). }\end{array}$ & $\begin{array}{l}\text { But the path of the righteous (נאור גנהיה), which shines } \\
\text { like a shining light } \\
\text { brighter and brighter until the middle of } \\
\text { the day (נכון היום). }\end{array}$ \\
\hline
\end{tabular}

Wait for Yahweh, and keep his way, and he will exalt you to inherit (ירש) the land; when the wicked are cut off (כרת ni), you will see it (Ps 37:34).

If there were any doubt whether Proverbs really served as the inspiration for the author of Psalm 37, the similarity between Psalm 37:5-6 and Proverbs 4:18 should be considered (see Table 2$).^{13}$

The characteristics of a righteous person, according to Psalm 37, are trust in Yahweh (vv. 3, 5; cf. Pr 3:5), doing what is good and practicing faithfulness (vv. 3, 27; cf. Pr 3:27; 12:22), taking delight in Yahweh (v. 4), silently waiting for Yahweh (vv. 7, 34), being humble (v. 11; cf. Pr 3:34), being gracious by giving to others and lending out (vv. 21, 26; cf. Pr 14:21, 31), and taking refuge in Yahweh (v. 40; cf. Pr 30:5). There is a conspicuous emphasis on the correct disposition before Yahweh, something which might point towards a redaction on behalf of the poor. ${ }^{14}$

But for an investigation of the impact of wisdom on Psalm 37, the most important characteristics of a righteous person are probably found in verses 30-31:

The mouth of the righteous utters wisdom (יהגה חכמה), and his tongue speaks justice. The law of his God is in his heart (תלהיו בלבו תורת); his steps do not slip.

This should be compared to Proverbs 2:10: 'For wisdom will enter into your heart (בלבך כיתבוא חכמה) and with Proverbs 8:7: 'For my mouth will utter truth (בלבר כמאי אמת יהגה חכי)' and wickedness is an abomination to my lips.'

It is clear from Psalm 37:30-31 that there is a close connection between wisdom and Torah in the mind of the author of this psalm. ${ }^{15}$ It seems that only someone who has the Torah of God as the true wisdom in his heart is able to utter wisdom, to speak justice and to prevent his steps from slipping. This is the kind of person who will inherit the land.

\section{The connection between Psalm 1 and Psalm 37 and the inheritance of the land}

The author of Psalm 1 considered the book of Proverbs as a valid source for creating a religious text about the 'Torah' of Yahweh. As was remarked above, Gosse has pointed out the similarity of the mentioning of the לִצִים [mockers] in Proverbs 1:22, Psalm 1:1, and Psalm 119:51 (Gosse 2006:390-391). The word occurs many times in Proverbs, but these are the only two occurrences in Psalms, a fact which should be seen as

13.So also Hossfeld and Zenger (1993:231).

14.Cf. Hossfeld and Zenger (1993:231) and, in greater detail, Levin (1993).

15.So also Weber (2006:99). significant. Gosse also noted the similarity between the introductory formulas of blessing in Psalm 1:1 and Psalm 119:1-2 and those in Proverbs 3:13 ('blessed is the man who finds wisdom, and the man who gains understanding') and also 8:32 ('blessed are they who keep my ways,' wisdom being the speaker) (Gosse 2006:391). These are indeed other instances of wisdom being replaced by Torah in wisdom Psalms such as Psalm 1 and Psalm 119.

But it seems the connection between Psalm 1 and Proverbs is even closer. Psalm 1 echoes the call of Proverbs 1:10-15 not

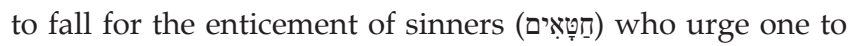
join in their murderous robberies, but rather to resist going 'with them on the way' (הלך בדרך אתם, v. 15). ${ }^{16}$ Wisdom then warns the mockers (לְצִים) in Proverbs 1:22 to stop 'delighting' (חמד) in mockery, since she will laugh at them and mock them when their destruction comes like a whirlwind (ספוָּ v, v. 27, cf. 'wind,' רוח, in Ps 1:4) since they would not accept her counsel (עָצָה) (v. 30; cf. Ps 1:1). Yahweh himself is later also said to 'scoff at the scoffers' (Pr 3:34). They will eat of the fruit (’ฺ̣) of their own way (Pr 1:31, cf. Ps 1:3). It is the complacency of these fools that destroys them (אבד pi, v. 32, cf. Ps 1:6, אבד qal). The two ways are also contrasted in Proverbs 2:12-20 and it is described how wisdom (חָכְכמָה) will save one from the way of evil and the ways of darkness, so that one can walk in the way of good men and keep to the paths of the

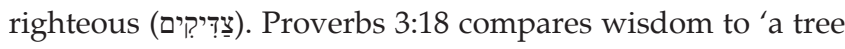

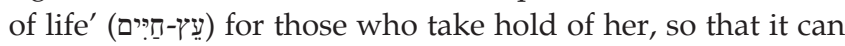
be seen that Psalm 1 has in fact here also substituted wisdom with Torah, since in this psalm it is the Torah that nourishes the righteous like canals nourish a tree (cf. Ps 1:2-3). ${ }^{17}$ It is no longer the wise who produce fruit like a tree of life (Pr 11:30), but those who meditate on the Torah of Yahweh (Ps 1:3). Finally, according to Proverbs 10:28 it is the 'hope' of the wicked that will perish (אבד), a pronouncement that reminds one of Psalm 1:6. ${ }^{18}$

There is no suggestion in this comparison between Psalm 1 and Proverbs that the author of Psalm 1 thought of the inheritance of the land as the reward for an attachment to the Torah of Yahweh. But the conspicuous links Psalm 1 has with Psalm 37, and the emphasis Psalm 37 places on inheritance of the land as the reward for piety through observance of the Torah as wisdom may suggest new insight into the meaning of Psalm 1 as well. It is certainly possible that it was Psalm 1 that inspired the author of Psalm $37,{ }^{19}$ but for the moment let us accept the dominant view that Psalm 1 was composed later than Psalm 37.20

16. Hossfeld and Zenger (1993:46) see a similar parallel with Proverbs 4:14, 'Do not set foot on the path of the wicked or walk in the way of evil men.'

17.For the second part of this statement, cf. Hossfeld and Zenger (1993:48), although he would add also the 'streams' of the book of Psalms itself.

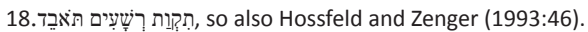

19.Weber (2006:99) interprets Psalm 37:30-31 'als Auslegung, ja als Folgerung von dem in Ps Gesagten.'

20. Hossfeld and Zenger (1993:45) recognise the role of Psalm 37 in the composition of Psalm 1, but regard Psalm 119 also as one of its sources. I would rather say that Psalm 119 is later than Psalm 1 and that its author made use of this text as well. Psalm 119 is later than Psalm 1 and that its author made use of this text as well.
Weber (2006:101) also understands Psalm 1 as the predecessor of Psalm 119: it concludes what Psalm 1 initiated. 
If that is indeed the case, it seems that the author of Psalm 1 made use of a host of images found in Psalm 37:21 Evildoers will wither like green herbs (נבל, Ps 37:2; cf. the opposite description of the righteous in Ps 1:3 as a tree the leaves of which do not wither); way-imagery is used extensively in both contexts, although this is a typical feature of wisdom texts and one that Psalm 1 also shares with Proverbs (cf. Ps 37:5, 7, 14, 23, 34); Psalm 37:7 urges the righteous not to be jealous of the success of someone who carries out wicked schemes (צלח hi is used to describe the success; cf. the opposite description of the righteous as the successful in Ps 1:3); Psalm 37:18 which

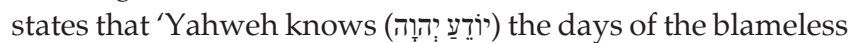
persons,' has a close parallel in Psalm 1:6 ('Yahweh knows

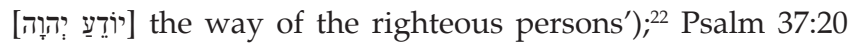

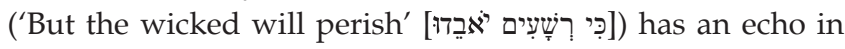

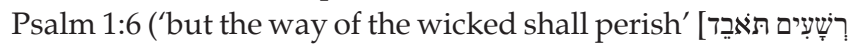

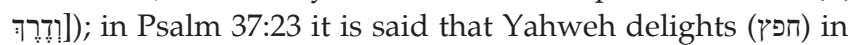
the way of a man, an expression which might have prompted the description of a righteous person as one whose delight (חפ) is in the Torah of Yahweh in Psalm 1:2; Psalm 37:30 describes the righteous as one whose mouth speaks (יִֶֶֶ: ) wisdom, whilst Psalm 1:2 describes the righteous as one

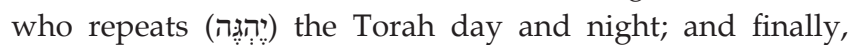
Psalm 37:35 speaks of a 'violent, wicked man' who 'spreads

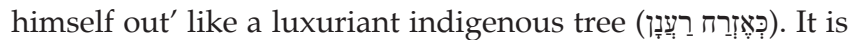
well known that the other instances of this word, 'luxuriant,' in Jeremiah 17:8, Psalms 52:10 and 92:11 and 15, occur in contexts that are known to have exerted an influence on the imagery of Psalm $1 .^{23}$ Once again, Psalm 1 has an opposing description of the righteous as the tree with foliage that does not wither. Whilst Psalm 37 exhorts the audience not to be angry or jealous of evildoers, but to trust in Yahweh, to do good and wait for Yahweh to act, Psalm 1 does not accept the possibility of evildoers being more successful than righteous people. The descriptions of the arrogant success of the wicked in Psalm 37 are seemingly turned into images of the blessing of the righteous in Psalm 1. And yet, the two psalms are very similar in the conviction that the wicked will be uprooted and cut off and will perish. Psalm 37:20 describes this as their disappearing like rich pastures that go up in smoke. ${ }^{24}$ The effect is very much the same as the description in Psalm 1 of the wicked being scattered by the wind like chaff. Since there are strong associations of the image of a transplanted tree with the settling of Israel in the Promised Land, ${ }^{25}$ it seems feasible that the author of Psalm 1 tried to suggest that those who meditate on the Torah and trust in the judgement of Yahweh are the only ones who will eventually inherit the land. Many of the other contexts with which Psalm 1 has indisputable

21.Reinhard Kratz (1996:9) has made a similar comparison and has also pointed out most of the similarities between the two psalms.

22.Also noted by Hossfeld and Zenger (1993:49)

23.Cf. the article of Creach (1999) and my article on Psalm 1 and intertextuality (Botha 2005).

24.If this is to be translated with 'as smoke,' the preposition must be understood as bet essentiae (Hossfeld \& Zenger 1993:233, n. on v. 20c).

25.Cf. the use of the passive of in contexts such as Ezekiel 17 and 19 and of the idea in general in Psalm 80. This may also be the reason why Psalm 1:3a was interpreted by the Midrashim on Psalms and Leviticus respectively as referring either to the by the Midrashim on Psalms and Leviticus respectively as referring either to the
planting of Adam in the garden of Eden or the planting of Abraham or Levi in the planting of Adam in the garden of
land of Israel. Cf. Creach (1999:44). connections also emphasise the possession of the Promised Land. In Joshua 1:6, Yahweh promises Joshua that he will give possession (נחל hi) of the land to the Israelites before he is given the command to meditate on the Torah in verse 8 . Deuteronomy 6 begins by reminding the Israelites that the commandments, statutes, and judgements are given so that they can be 'done' (עשה) 'in the land where you are going over to possess it (ירש (Dt 6:1). The close parallel to Psalm 1 then follows in verses 6-7. After the shema, the gift of the land is once again referred to (Dt 6:10). The important context of Ezra 47 concludes, after a description of the stream of water coming from the temple and the fruit trees nourished by it, by redrawing the boundary 'by which you are to divide the

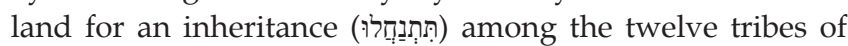
Israel' (Ezr 47:13, cf. 47:14 where the stem נחלוחל is used another two times).

The image of the evergreen fruit tree which gives its fruit unfailingly also has strong reminiscences of the fruitfulness of the land which Yahweh promised on condition that the commandments were complied with: Leviticus 26:3-4, Deuteronomy $11: 14,{ }^{26} 26: 2,10$, and 28:11-12 come to mind. ${ }^{27}$ Especially Leviticus 26:3-4 seems to form a parallel to Psalm 1:

If you walk (הלך) in my statutes and keep my commandments so as to do them (עשה), then I shall give you rains in their season (בעת), so that the land will yield (נתן) its produce and the trees (ערן) of the field will bear their fruit (פרין).

It is significant that both Psalm 1 and Psalm 37 have strong ties with Joshua 1, the chapter in which Joshua is conscripted to take possession of the Promised Land. The connection between Psalm 1 and Joshua 1:7-8 is well known. ${ }^{28}$ It seems possible that this connection was inspired by the author of Psalm 1's knowledge of Psalm 37, since the author of Psalm 37 definitely made use of Joshua 1 as well: The occurrence of the words 'to take possession' (ירש in Jos 1:11, 15 and Ps 37:9, 11, 22, 29, 34), 'to do' (עשה, Jos 1:7, 8, 16 and Ps 37:3, 5, 27), 'mouth' (פה) and 'meditate' (הגה) in close proximity to the Torah (Jos 1:8; Ps 37:30 respectively), 'keep' (שמר) (Jos 1:7, 8; Ps 37:34), 'deviate' (סור, Jos 1:7; Ps 37:27), 'be successful in one's ways' (צלח, Jos 1:8 \& Ps 37:7), and Yahweh's promise not to abandon the faithful (לא עזב, Jos 1:5; Ps 37:25, 28, 33) seems to be convincing evidence in this regard.

In summary, it thus seems that the author of Psalm 1, very similar to the author of Psalm 119, created a religious text by alluding to and rephrasing sections of Scripture that must have been regarded by him as authoritative material. Since wisdom material such as Proverbs and Psalm 37 are included in the library from which he drew inspiration, and since he endorsed the substitution of 'wisdom' by 'Torah' made before his time by the authors of Palms 19 and 37, a book such as Proverbs must surely have been regarded by him as part of the 'Torah' of Yahweh. There seems to be evidence, furthermore, that he expected the judgement of Yahweh 26. Investigated in detail in Weber (2006:91-92).

27.Cf. Weber (2010).

28.Cf. the discussion and overview in Weber (2006:92-95). 
on the wicked and the restoration of the Promised Land to the 'righteous' who found their joy in the Torah of Yahweh, that is, who lived according to his revealed will in Scripture. Psalm 37:4 urges the faithful to find joy in Yahweh (ענג hitp) and promises that they will enjoy (ענג hitp) abundant peace (Ps 37:11); for the author of Psalm 1 there is joy (חפקץ) in having the Torah of Yahweh to meditate upon.

\section{Psalm 119's interpretation and use of wisdom texts in defining 'Torah'}

It thus seems that the modern researcher has to understand the final phase of the growth of the book of Psalms in terms of a constantly growing circle of literary influence which served as a source for the creation of new religious texts. ${ }^{29}$ In these new creations one has to note not only the allusions to and quotations from the earlier material, but especially the critical attitude of the author in reinterpreting earlier material. The authors of Psalms 19 and 37, we have seen, have incorporated and reinterpreted Proverbs to show that true wisdom equals the Torah of Yahweh. The author of Psalm 1 has made use of a wide variety of texts, most probably all of which were considered to be authoritative material by him: Deuteronomy, Joshua, Jeremiah, Ezekiel, Psalms, Job, and Proverbs seem to be the most important corpuses. All these contexts were probably included when he thought of the 'Torah' of Yahweh as the comprehensive teaching of Yahweh in Scripture, since he made the same connection between wisdom and the Torah of Yahweh as did the authors of the other wisdom psalms.

The author of Psalm 119 most probably had in his library copies of Deuteronomy (he was fond especially of Dt $4: 19 ; 6: 1-7),{ }^{30}$ the early Prophets (he was fond of the prayers in these texts), ${ }^{31}$ Isaiah (esp. ch. 64), ${ }^{32}$ Jeremiah (he found the figure of Jeremiah to be typical of his own person), ${ }^{33}$ Ezekiel, Proverbs (especially Pr 1-9), Job, (Deißler 1955:274), Lamentations, and Psalms (especially the acrostic and other wisdom Psalms such as Pss 19, 25, 33, 37, 67, 134, 139, 147) (Deißler 1955:265-267). What has probably not yet been investigated satisfactorily is the relationship between Psalm 119 and Psalm $1 .^{34}$ It seems that the author of Psalm 119 deliberately incorporated Psalm 1 into his composition by beginning with a double formula of blessing (vv. 1, אבד ('stray like a sheep,' v. 176), a word that also occurs in the last verse of Psalm 1. Other similarities between the two

29.Christoph Levin would probably argue, apart from new (mostly acrostic) creations, for a reworking of existing psalms in this phase in which the opposition between ( rere pre the driving inspiration. Cf. Levin (1993:355-381). The many known and proposed revisions of the book of Psalms he mentions (Levin 1993:380) serve as an indication of how complex the process of redaction of the Psalter in fact was. Wilson (1986:92) has remarked that the wide variation in the formal structure of the doxologies which conclude the various books of the Psalter would seem to suggest that they derive from independent redactional efforts.

30.Cf. Deißler (1955:270-271).

31.Cf. Deißler (1955:276).

32.Cf. Deißler (1955:275-276).

33.Terrien (2003:805) stresses the connection with Jeremiah and Jeremianic literature in particular.

34.Wilson (1985:223) speaks of a 'clear relation' of Psalm 119 with Psalm 1 and mentions in this regard the blessing of the student of Torah and the emphasis on the contrasting 'ways' of the righteous and the wicked. psalms include the role accorded to 'Torah,' the extensive use of road imagery, the importance attached to meditation on the Torah, ${ }^{35}$ the joy that this provides, and the description of his continual involvement with the Torah, similar to the qualification of the righteous in Psalm 1 as someone who meditates 'day and night' on it. In this regard, Psalm 119 almost seems like a commentary on Psalm 1:1-2 and it is hard to accept that the very precisely constructed and terse Psalm 1 should be seen as the summary of Psalm 119. For the sake of comparison, and to argue that Psalm 119 is the younger text, Psalm 1 is quoted below with words or ideas taken up in Psalm 119 put in italics and with footnotes indicating the way in which these ideas were alluded to in Psalm 119:

1. Blessed $d^{36}$ is the man who walks ${ }^{37}$ not in the counsel ${ }^{38}$ of the wicked, ${ }^{39}$ nor stands in the way ${ }^{40}$ of sinners, ${ }^{41}$ nor sits $^{42}$ in the seat of scoffers; ${ }^{43}$ 2. but his delight $t^{44}$ is in the law of Yahweh, ${ }^{45}$ and on his law he meditates ${ }^{46}$ day and night. ${ }^{47} 3$. He is like a tree planted by streams of water ${ }^{48}$ that yields its fruit in its season, and its leaf does not wither. In all that he does, he prospers. 4 . The wicked ${ }^{49}$ are not so, but are like chaff which the wind drives away. 5 . Therefore the wicked will not stand in the judgement, ${ }^{50}$ nor sinners in the congregation of the righteous; 6. for Yahweh knows the way of the righteous, but the way of the wicked will perish. ${ }^{51}$

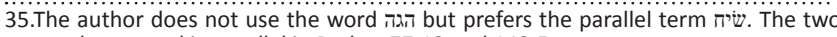
words are used in parallel in Psalms 77:13 and 143:5.

36.Psalm 119 begins with a double blessing in verses 1 and 2 , seemingly transcending Psalm 1.

37. Road imagery, in which הלרק and/or are used similarly to what is the case in Psalm 1, occurs in verses 1, 3, 5, 14, 26, 27, 29, 30, 32, 33, 37, 45, 59, 101, 104 (ארח), 128 (ארח), 105 (נרחיב), and 168 (a verse very similar in meaning to Ps 1:6a).

38.Yahweh's 'testimonies' are described as the 'counsellors' of the suppliant (v. 24).

39.The רשעים are mentioned in verses 53, 61, 95, 110, 119 and 155.

40.See the note on road imagery above.

41.The verb 'to sin' (חט) is used in verse 11

42.In verse 23, the suppliant mentions 'princes' 'sitting' (ישב) and plotting against him.

43.The לצים of Psalm 1 feature in Psalm 119 only in the verb ליץ (v. 51), but the persons who display this disposition are present throughout the psalm. They are called 'insolent' people (זדים, vv. 21, 51, 78, 85, 122); they are seen as the source of 'scorn' and 'contempt' (חרפה וברוז, v. 22; cf. vv. 39, 42) for the suppliant, and are

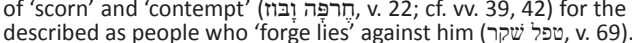

44.To describe his delight or joy in the Torah, the author of Psalm 119 uses the verb

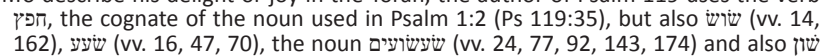
ש (v. 111).

45.The 'Torah' is referred to 25 times in Psalm 119, but four times the delight of the suppliant in the Torah is mentioned expressly (vv. 70, 77, 92, 174). This constitutes a close parallel to Psalm 1:2.

46.For 'meditate,' the author of Psalm 119 uses - instead of הגה - the parallel term שיח (vv. 15, 23, 27, 48, 78, 147) and also the noun שיחה 'meditation' (vv. 97, 99).

47.The many variants Psalm 119 uses for meditation by 'day and night' in Psalm 1:2 perhaps give the clearest indication that the author is replicating this idea without using the exact words. They include: 'in the night' (v. 55), 'at midnight' (v. 62), 'the whole day long' (v. 97), 'before dawn' (v. 147), 'before the watches of the night' (v. $148)$, and 'seven times a day' (v. 164)

48.The 'streams of water' of Psalm 1:3 is not used to describe the benefit of meditation on the Torah, but in a lament: 'My eyes shed streams of water because they do not keep your Torah' (v. 136). Although the context is the opposite of Psalm 1:3, the expression is still used to express attachment to the Torah of Yahweh.

49.The wicked are not compared to chaff in Psalm 119, but to 'dross' (גיג, v. 119). This refers to lead oxide, the useless by-product when silver was melted, so that this forms a parallel to Psalm 1:4 in a certain sense.

50.The judgement of Yahweh is mentioned a number of times in Psalm 119 (vv. 75, $84,120,137)$. In general, however, the author of Psalm 119 does not express the outcome of Yahweh's judgement as much as his eagerly awaiting it: 'When will you execute judgement?' (v. 84); 'It is time for Yahweh to act' (v. 126).

51.In Psalm 119 it is the suppliant who would have perished if it were not for the Torah that was his delight (v. 92), it is the wicked who wanted to finish him off (v. 95), and it is he himself who wandered off like a stray sheep (v. 176). 
As one could probably expect, Psalm 119 continues in the vein of Psalms 19, 37, and 1 by substituting wisdom with Torah. The comparison of Proverbs 3:13-14, that it is better to find wisdom than to find silver and fine gold, is matched by Psalm 119:72 which states that Yahweh's Torah is better than thousands of pieces of gold and silver. Whilst it is wisdom that makes one wise (שכל hi) according to Proverbs 1:2-3, Psalm 119:99 insists that it is meditation on the testimonies of Yahweh that gives understanding (שכל hi). When Proverbs 2:1 (cf. 7:1) urges one to 'treasure up' (צפן) the commandments of the wisdom teacher, the suppliant in Psalm 119:11 confesses that he 'treasured up' (צפן) the word of God instead. Proverbs 8:18 promises that wisdom will give enduring riches (הון), but the author of Psalm 119:14 insists that he rejoices in the testimonies of Yahweh as in riches (הון). The audience of Proverbs 4:5 is exhorted to acquire wisdom and not to forget the words (אמרים) of the wisdom teacher. The author of Psalm 119 repeatedly states that he will not forget the word (דבר) of Yahweh (v. 16), or his Torah (vv. 61, 109, 153), nor the statutes (v. 83), the precepts (v. 93, 141) or the commandments (v. 176). Wisdom is something to be acquired and to be loved, according to Proverbs 4:5-6, 8:17 and 20. 'Love' is precisely what the author of Psalm 119 does with the commandments (vv. 47,48, 127), the Torah (vv. 97, 113, 163, 165), the testimonies (vv. 119,167), the word of Yahweh (v. 140) and his precepts (v. 159). Proverbs 30:5 and Psalm 119:140 concur that the word of Yahweh is refined (צר), although

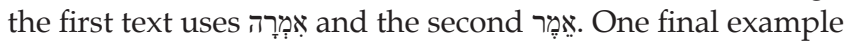
should suffice to show how Proverbs is reinterpreted by the author of Psalm 119: According to Proverbs 3:19, Yahweh founded (יצ') the earth through wisdom. The author of Psalm 119 states in verse 152 that it is the testimonies of Yahweh that are 'founded' (ציד) forever. This is clear proof that the role accorded to wisdom in creation, as it is expressed in Job 28:23 and 25-27, and also in Proverbs 8:22-31, is taken over by Torah in the mind of the author of Psalm 119. The clearest indication of this can be found in verses 89-92 which contain an explicit reinterpretation of the role of wisdom in creation (cf. Botha 1986:378).

Two further differences between Psalm 119 and other wisdom texts should be mentioned. Where Psalm 37:9 and 34 (cf. v. 7 with its textual problem) exhorts its audience to 'wait for Yahweh,' the suppliant of Psalm 119 is willing to simply 'wait' for the Torah of Yahweh: his 'judgements' (v. 43), and his 'word' (v. 74, 81, 114, 147). The Torah seems to function as a substitute for Yahweh in these instances, indicating how authoritative the body of literary religious material had become by then.

The second difference is a tendency to regard the material rewards promised to those who heed wisdom as a spiritual reward for those who have a proper regard for the Torah. It was already noted above how wisdom promised 'enduring wealth' (הוֹן עַתֵק) in Proverbs 8:18, but that the author of Psalm 119 confessed to experience joy in the 'way of (Yahweh's)

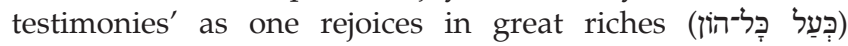
(Ps 119:14). Where Psalm 37 and Psalm 1, according to the findings of this investigation, see the way to success and blessedness (and possession of the land) as walking in the Torah of Yahweh - with Torah representing true wisdom as it is revealed in the whole of Scripture - the author of
Psalm 119 would rather say that success and blessedness is to have the opportunity to walk in the Torah as the revealed will of God. Scripture is God's gift to the faithful. Verse 111 states, for instance, 'I have inherited (נחל) your testimonies forever, for they are the joy of my heart.' To 'inherit' is the classical term for the division of the Promised Land and for taking possession of it (Deißler 1955:209). The closest parallel to the expression used here is found in Exodus 32:13 where Moses reminds Yahweh of his promise to give Canaan as an everlasting inheritance to the Israelites. In comparison to Psalm 37, the end purpose for the righteous is not to have possession of the land forever, ${ }^{52}$ and it is not to inherit property and acquire full treasuries as wisdom promises to those who hold on to her (Pr 8:21), but simply enjoyment of the Torah. This seems to be the reason why the aspect of delight or joy in the Torah (which is also found in Ps 1) is expanded to such proportions in Psalm 119. ${ }^{53}$ Psalm 119:19 also seems to suggest that the suppliant has accepted the fact that he is a stranger in the land. ${ }^{54}$ The same idea is expressed also in Psalm 119:54: 'Your statutes were songs to me in the house of my temporary citizenship.'

Deißler (1955:130-132, 211) has argued that verses 33 and 112 provide the clearest evidence that the author had transcended the idea of a material reward for piety, still expressed in Proverbs 1-9, and that he described a life according to the revealed will of God in itself as profit, good fortune and grace. His argument is based on the meanings of the word uñקב, usually translated in these two verses with 'to the end': Psalm 119:33, 'Teach me, Yahweh, the way of

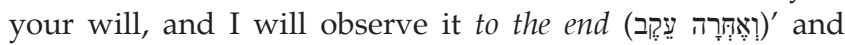
Psalm 119:112, 'I have inclined my heart to perform your statutesforever, to theend.' Heargues that itshouldbetranslated in both instances 'as reward,' since the form does not have a temporal meaning anywhere else in the Old Testament and this was a very late development of the meaning in Aramaic, which, according to him, caused the misinterpretation of the translator of the LXX. The author probably had Psalm 19:12 (in the keeping of Yahweh's judgements there is 'great reward' (רב עק), Deuteronomy 7:12 ('the reward will be if you listen ...'), and Proverbs 4:13 ('Hold on to instruction, do not let it go; guard it well, for it is your life') in mind. This last context does not contain the word עקב נצר for 'observe,' the same as Psalm 119:33, and describes 'life' as the reward. The argument is that the author substituted 'instruction' with 'Torah' and 'life' as a reward with עיקֶ, so that the keeping of the Torah itself should be seen as a reward.

I do not want to express an opinion on this thesis of Deißler, since Psalm 119 is a very late text in which the meaning of עיקבב could already have changed. The asyndetic insertion of the term in verses 33 and 112 also causes some doubt about his interpretation. ${ }^{55}$ But it is clear from other verses in Psalm 119 that dedication to the Torah of Yahweh is no longer a means

52.Cf. Psalm 37:18, where it is said that the [inheritance] of the blameless persons will be 'forever'

53.Partly using wisdom-like descriptions!

54.I am not convinced by Deißler's arguments that ארץ should be translated here as 'earth' on the basis of David's prayer in 1 Chronicles 29:15. Cf. Deißler (1955:112).

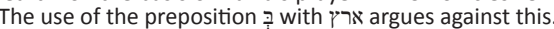

55.Seybold (1996:463, 467), in following Deißler, translates in verse 33 'Lehre mich JHWH, den Weg deiner Gesetze, damit ich ihn verfolge als Ziel!,' but in verse 112 keeps to the temporal meaning ('allezeit bis zum Ende'). 
of obtaining blessing, but a blessing in itself. The Torah is the Promised Land for the author. Psalm 119:55-57 state:

In the night I remembered your name, Yahweh, and I kept your Torah. This has become mine, that I observe your precepts. My portion, Yahweh, I said, is to keep your words.

Verse 98 notes in a similar vein: 'Your commands make me wiser than my enemies, for it (היא) is mine forever.' The word used in verse 57 , has reminiscences of the conquest of Canaan. Similar to נחלה, it calls the partitioning of the Promised Land to mind (Deißler 1955:157)..$^{56}$ The tribe of Levi did not receive a separate portion of land, and it is said in Deuteronomy 10:9 that Levi did not receive חלק [portion] and נחלה [inheritance], but that Yahweh would be his נחלה. This gave rise to the figurative use of the word in which Yahweh is described as the 'portion' of the suppliant in Psalms 16:5, 73:26, and 142:6. The author of Psalm 119 adapted this to describe the Torah of Yahweh as his share in life.

\section{Conclusion}

Psalm 119 uses eight synonyms to refer to the diverse aspects of the Torah of Yahweh. I have argued elsewhere ${ }^{57}$ that the syntagmatic connections of these terms indicate that although they are interchangeable to a certain extent - some of them belong to the domain of 'instruction' terms, aspects of the Torah which should be observed, complied with, and meditated upon, ${ }^{58}$ whilst others belong to the domain of 'word' terms ${ }^{59}$ aspects of the Torah from which promises and hope about salvation are drawn by the suppliant. ${ }^{60}$ The allusive intertextual connections made by the author indicate that the Pentateuch, the Prophets, wisdom material, and Psalms, even Lamentations, were included in his understanding of Torah as a comprehensive arch-lexeme for the revealed will of God and the record of his dealings with Israel. This should not be surprising, since the same 'anthological' and inclusive understanding of 'Torah' was detected in Psalm 1. Similar to Psalm 19, Psalm 37, and Psalm 1, Ps 119 has also recast wisdom as Torah. But the focus has shifted between these texts and Psalm 119: Torah in the clothes of wisdom is no longer seen as a way to the gift of possession of the Promised Land, but as the gift itself.

How does Psalm 119 help us to understand 'Torah' in Psalm 1? I should think that it helps us to see that Psalm 1 served as an example of an anthological text to the author of Psalm 119 in which use was made of all sections of the Tanakh, including wisdom material such as Proverbs and Psalm 37. It should help us to recognise that the author of Psalm 1 probably saw 'Torah' - similar to the author of Psalm 119 at a later stage as a comprehensive term which included regulatory aspects 56.Deißler (1955) refers to Joshua 15:13, Micha 2:4, Ezra $45: 7$ and $48: 8$ and 21 .

57.Botha (1989:3-22)

58.The words תורה and מקודים , מצות , עדות הקים.

59.The remaining three words, אמרה and דבר and משפט

60.Verbs of observance are used on average 10 times with each of the 'instruction' terms in comparison to 4 times with each of the 'word' terms; verbs describing salvation are used on average once with each of the 'instruction' terms in comparison to 9 times for each of the 'word' terms; and verbs describing meditation are used on average 7 times with each of the 'instruction' terms, in comparison to only 3 times with each of the 'word' terms. that had to be meditated upon and used as a guide on the way of life, but that the promises of prosperity in the Promised Land, judgement on the wicked, and care for the faithful in a life before Yahweh were probably also included in 'Torah' in its representation of the true wisdom of Yahweh. This means that the Psalter itself, or at least that part of the Psalter that existed at the time, forms part of the 'Torah of Yahweh,' but that the term in Psalm 1 hardly referred only to the Psalms as the 'Torah of David.' ${ }^{\prime 1}$

\section{Acknowledgements Competing interests}

The author declares that he has no financial or personal relationship(s) which may have inappropriately influenced him in writing this article.

\section{References}

Botha, P.J., 1986, 'Die teologiese funksie van die Torah-woordveld in die driehoeksverhouding Jahwe-vrome-vyand in Psalm 119', ongepubliseerde DD-proefskrif, Departement Ou Testament, Universiteit van Pretoria.

Botha, P.J., 1989, 'The measurement of meaning - an exercise in field semantics', Journal for Semitics 1(1), 3-22.

Botha, P.J., 2005, 'Intertextuality and the interpretation of Psalm 1', Old Testament Essays 18(3), 503-520.

Botha, P.J., 2008, 'Annotated History - The Implications of Reading Psalm 34 in Conjunction with 1 Samuel 21-26 and Vice Versa', Old Testament Essays 21(3), 593-617.

Botha, P.J., 2010, “"A world firmly established on Water": The Wisdom Foundations of Psalm 24:1-2'" in S. Fischer \& M. Grohmann (Hrsg.), Weisheit und Schöpfung, Festschrift für James Alfred Loader zum 65. Geburtstag, pp. 43-58, Peter Lang, Wien. (Wiener Alttestamentliche Studien, Band 7).

Botha, P.J., 2011a, "'Freedom to roam in a Wide Open Space." Psalm 31 Read in Conjunction with the History of David in the Books of Samuel and the Psalms', in W. Dietrich (Hrsg.), Seitenblicke, pp. 424-442, Vandenhoeck \& Ruprecht, Göttingen/Academic Press, Fribourg. (Literarische und historische Studien zu Nebenfiguren im zweiten Samuelbuch, Orbis Biblicus et Orientalis 249).

Botha, P.J., 2011b, 'Poetry and Perlocution in Psalm 26', Old Testament Essays 24(1), 30-48.

Botha, P.J., 2012a, 'Pride and the Suffering of the Poor in the Persian Period: Psalm 12 in its Post-Exilic Context', Old Testament Essays 25(1), 40-56.

Botha, P.J., 2012b, 'Psalm 91 and its Wisdom Connections', Old Testament Essays 25(2), 260-276.

Botha, P.J. \& Potgieter, J.H., 2010, "'The Word of Yahweh is right" - Psalm 33 as a Torah-psalm,' Verbum et Ecclesia 31(1), 1-8.

Creach, J.F.D., 1999, 'Like a tree planted by the temple stream: The portrait of the righteous in Psalm 1:3', The Catholic Biblical Quarterly 61(1), 34-46.

Deißler, A., 1955, Psalm 119 (118) und seine Theologie, Karl Zink, München. (Ein Beitrag zur Erforschung der anthologischen Stilgattung im Alten Testament. Münchener Theologische Studien, 11).

Gosse, B., 2006, 'Le livre des Proverbes, la Sagesse, la Loi et le Psautier', Etudes Théologiques et Religieuses 81, 387-394.

Gosse, B., 2008, L'influence du Livre des Proverbes sur les Rédactions bibliques à l'époque Perse, Gabalda, Paris. (Supplément 14 à Transeuphratène).

Hossfeld, F-L. \& Zenger, E., 1993, Die Psalmen I. Psalm 1-50, Echter, Würzburg.

Kratz, R.G., 1996, 'Die Tora Davids. Psalm 1 und die doxologische Fünfteilung des Psalters', Zeitschrift für Theologie und Kirche 93, 1-34.

Levin, C., 1993, 'Das Gebetbuch der Gerechten. Literargeschichtliche Beobachtungen am Psalter', Zeitschrift für Theologie und Kirche 90, 355-381.

Millard, M., 1994, Die Komposition des Psalters: Ein formgeschichtlicher Ansatz, J. C. B. Mohr (Paul Siebeck), Tübingen. (Forschungen zum Alten Testament 9).

Seybold, K., 1996, Die Psalmen, J.C.B. Mohr, Tübingen. (HAT I/15).

Terrien, S., 2003, The Psalms: Strophic structure and theological commentary, Eerdmans, Grand Rapids, MI/Cambridge, UK. (The Eerdmans Critical Commentary).

Weber, B., 2006, 'Der Beitrag von Psalm 1 zu einer "Theologie der Schrift"', Jahrbuch für evangelikale Theologie 20, 83-113.

Weber, B., 2007 'Psalm 1 als Tor zur Tora JHWHs. Wie Ps 1 (und Ps 2) den Psalter an den Pentateuch anschliesst', Scandinavian Journal of the Old Testament 21(2), 179-200. http://dx.doi.org/10.1080/09018320801896518

Weber, B., 2010, “"Dann wird er sein wie ein Baum..." (Ps 1:3). Zu den Sprachbildern von Psalm 1', Old Testament Essays 23(2), 406-426.

Wilson, G.H., 1985, The editing of the Hebrew Psalter, Scholars Press, Chico. (SBL Dissertation Series, 76).

Wilson, G.H., 1986, 'The use of Royal Psalms at the "seams" of the Psalter', Journal for the Study of the Old Testament 35, 85-94. http://dx.doi. org/10.1177/030908928601103505

Wilson, G.H., 2002, Psalms, vol. 1, Zondervan, Grand Rapids. (The NIV Application Commentary. From biblical text ... to contemporary life).

61.Reinhard Kratz formulates it like this: "So sind Torah Jhwhs und Psalter zwar nicht dasselbe Buch, aber in der Sache kongruent, wenn nicht identisch' (1996:11). 